\title{
The Roles of Germin Gene Products in Plants Under Salt Stress
}

\author{
Mahmut Caliskan \\ Mustafa Kemal University, Faculty of Arts \& Sciences \\ Biology Department, Hatay \\ Turkey
}

\section{Introduction}

The members of plants response various internal and external signals differently. The responses of plants to biotic and abiotic stress factors involve biochemical, physiological, morphological and developmental changes. Among the various circumstances salt stress is particularly under extensive studies due to low salt tolerance of crop plants. Germin and germin-like gene products were previously announced to be involved in various aspects of plant development such as plant defence, embryonic development and they are responsive to biotic and abiotic stress including salt. The responses of germin and germin like genes to salt stress are found to be various in different plants.

The salinity of soil is an important problem in agriculture, particularly since the majority of crop plants have low salt tolerance. The response of plants to salt stress is a complex phenomenon that involves biochemical and physiological processes as well as morphological and developmental changes (Flowers et al., 1977; Greenway \& Munns, 1980). The identification of genes whose expression enables plants to adapt to or tolerate to salt stress is essential for breeding programs, but little is known about the genetic mechanisms for salt tolerance. One approach in clarifying the molecular mechanisms involved in salt stress is to identify the genes whose levels change as a result of salt stress. In this aspect, Hurkman et al. (1989) reported that in barley, gene regulation is altered by salt stress and the levels of translatable mRNAs change with salt treatment. Among the salt stress responsive gene products, germin and germin-like proteins (GLP) were identified (Caliskan, 1997; Hurkman et al., 1989). Cereal germin protein is a homopentameric apoplastic glycoprotein whose synthesis is associated with the onset of growth in germinating wheat embryos (Lane, 1991). Germin genes and their proteins were first detected in germinating cereals (Grzelczak et al., 1985), but subsequently, germin-like proteins were also identified in dicotyledonous angiosperms (Michalowski and Bohnerd, 1992), gymnosperms (Domon et al., 1995) and mosses (Yamahara et al., 1999). Germins are suggested to be a member of "superfamily" which comprises various growth-related genes (Dunwell et al., 2000).

Cereal germin proteins display strong oxalate oxidase activity (Lane et al., 1993), an activity that generates one mole of $\mathrm{H}_{2} \mathrm{O}_{2}$ and two moles of $\mathrm{CO}_{2}$ from the degradation of oxalic acid. It is reported that $\mathrm{H}_{2} \mathrm{O}_{2}$ might act as a signaling molecule at low concentration (Luthell, 1993) or a component of cell wall modifications at high concentrations (Showalter, 1993). Another germin-like protein isolated from the cells of a moss, Barbula unguiculata, was 
shown to have manganese superoxide dismutase activity (Yamahara et al., 1999). Germin genes and proteins have been shown to be associated with various aspects of plant development (Caliskan, 2000; Lane, 2002) such as defense system (Berna and Bernier, 1999; Donaldson et al. 2001), embryonic development (Caliskan and Cuming, 2001), photoperiodic oscillations (Ono et al. 1996), and hormonal stimuli (Berna \& Bernier, 1997). The accumulation of germin gene products in wheat and barley seedlings in the presence of $\mathrm{NaCl}$ was analyzed previously, but little is known about the possible role of germin gene products during salt stress (Hurkman et al., 1991, 1994; Hurkman \& Tanaka, 1996a; Berna \& Bernier, 1999).

In this paper, we have brought together the results of our studies and the results of other researchers who are working in the field of germin, germin-like proteins and their enzymatic activities.

\section{The stress factors and the early plant development}

Plants are a distinct kingdom of organisms that possess unique properties of reproduction, development, physiology and metabolism. The early development of plants is also quite different from that of animals in various ways. The main features that distinguish embryogenesis in angiosperms from the related pathways in animal systems are (1) the process of double fertilization and the subsequent interaction between embryo and endosperm, (2) the totipotency of certain plant cells by contrast with the uniqueness of the zygote in animals, (3) the activation of large numbers of zygotic genes during very early stages of embryogenesis, (4) the formation of apical meristems which produce the basic body plan of the "adult" plant, (5) the absence of a germ line established early in development, (6) the absence of cellular migration during embryo development. Due to the above discrepancies, studies of animal systems (e.g. Drosophila) may not be directly applicable to plants.

Embryogenesis is a developmental stage which covers the time period beginning with the formation of the zygote and ending with the formation of a mature embryo within a seed. Embryogenesis has a central role in the life cycle of flowering plants since it results in the production of a structurally and functionally organized miniature adult plant which is called the embryo. The conversion of an ovule into a seed is triggered by fertilization. The cells in male (anther) and female (ovary) organs of the flower undergo meiotic and mitotic divisions which give rise to a male gametophyte (pollen grain) and a female gametophyte (embryo sac). The pollen grain contains two sperm cells, whereas the embryo sac contains only a single egg cell in association with a number of accessory haploid cells. Upon penetration of the embryo sac by the pollen tube, one of the sperm nuclei fertilizes the egg cell, while the other unites with the two additional haploid nuclei of the embryo sac to form the triploid endosperm. Therefore, unlike animal fertilization, plants undergo a double fertilization process. As the ovule develops into a seed after fertilization, the zygote enters a pathway of cell division and differentiation to produce an embryo. At the end of this pathway, the embryo is composed of an embryonic axis that bears the root meristem at one end, the cotyledon(s) and the shoot meristem at the other end. Based on the cotyledon number, angiosperms are defined as monocotyledonous or dicotyledonous plants. The endosperm tissue may comprise the bulk of the mature seed, as a storage tissue, as in the case of cereal grains, or it may be reduced in size and importance in seeds where the principal storage reserves are kept within the cotyledons, in dicotyledonous seeds. 
In seeds of dicotyledonous plants, the embryo is typically comprised of an axial region (root and shoot) and two large cotyledons. The other organs are rudimentary, at best. By contrast, in monocotyledonous seeds the embryonic organs are usually highly differentiated at maturity. Primary root, numerous leaf primordia, shoot apex and coleoptile are well developed in cereal embryonic axes. Moreover, in monocots the cotyledon is often modified to form a relatively diminutive scutellum; whilst the endosperm is a large structure at maturity and is the main storage tissue. In wheat embryogenesis, five characteristic morphological stages have been identified by Rogers \& Quatrano (1983). Fertilization and the subsequent stages of cell proliferation and differentiation end in the production of a functionally mature embryo. This embryo can germinate immediately, but normally it remains in a state of suspended growth (dormancy). The early stages of plant embryo development are characterized by cell division and morphogenesis. For instance, during wheat embryogenesis ( $\sim 7$ weeks), the zygote $\left(1\right.$ cell) gives rise to a mature embryo $\left(\sim 10^{5}\right.$ cells) and the DNA content of the organism increases correspondingly (105-fold) (Lane, 1988). This is followed by a period of cell specialization and embryonic maturation in preparation for coming dormancy and germination periods.

Dormancy is not a period of metabolic inactivity because this period is characterized by the massive accumulation of storage materials in the appropriate tissues or organs, causing an increase in size and weight, the maturation stage. There are some proteins which characterize this stage of embryo development such as Em "Embryo maturation" and LEA "Late Embryogenesis Abundant" proteins. LEA polypeptides are non-storage proteins and synthesized during stage 3 of embryogenesis. It has been suggested that non-storage LEA proteins might be involved in the acquisition of desiccation tolerance, during stage 4, which is a characteristic feature of the development of most seeds (Galau et al., 1986). The most abundant cytosolic wheat embryo protein is the Em protein in mature embryos (Grzelczak et al., 1982). Levels of the Em polypeptide increase rapidly in the cytosol and continue throughout desiccation of the embryo. Upon subsequent imbibition, both the mRNA and its polypeptide product are rapidly degraded, and completely disappear by 24 hours postimbibition (Cuming, 1984). It was suggested that Em could have a limited storage function but was more likely to be associated with the acquisition of desiccation tolerance of embryo during embryogenesis and it is considered to be an example of the "group-1" LEA polypeptides (Butler \& Cuming, 1993; Galau et al. 1986). The dormant condition is relieved only by the final stage in seed development, dehydration. Dehydration is an essential part of embryo development, being both necessary to maintain seeds in a viable form for long time periods and to effect a switch in their pattern of development. Seed desiccation also effects a permanent change in metabolism, in that, upon rehydration, synthesis of proteins associated with development ceases, and that associated with germination and seedling establishment commences. During the maturation period, the embryo accumulates reserve compounds in an effectively anabolic lifestyle. As a result of dehydration, the embryo is potentiated to germinate immediately upon the rehydration, its metabolic activity switched towards the massive catabolism of storage compounds to support growth.

During the early cell division stage of development, very little storage material is synthesized. Most of the synthesis of storage proteins, carbohydrates and lipids takes place during subsequent cell expansion. The final stage of seed development is characterized by the loss of water during maturation drying, when reserve synthesis stops and the seed becomes metabolically inactive. Drying of the seed enables the embryo to be a dispersal structure that is resistant to environmental disturbances and that remains quiescent until 
conditions are suitable for germination and growth. Germination of the seed starts with the imbibition of water, resulting in the rapid resumption of protein synthesis, using those components of the synthetic complex conserved within the dry seed. Upon emergence of the radicle from the seed, germination is complete and the seedling becomes established, with the rapid elaboration of the clearly defined root and shoot regions. During the early development ( 2 days) of a mature wheat embryo $(<1 \mathrm{mg}$ ) into a seedling ( $>10 \mathrm{mg}$ ), the rapid and striking (> 10 fold) increase in mass is accompanied by limited cell division (Lane, 1988), and must therefore be a consequence of cell expansion driven by water uptake. This change in the size of the cells must necessarily involve significant adjustments in the structure of the extra cellular matrix (ECM) (apoplast, cell walls) in the growing seedling.

The role of plant growth regulators in the germination process is uncertain although it is known that exogenous application of abscisic acid inhibits germination in many species, while gibberellic acid promotes germination. However, the relationship between these experimental phenomena and the embryo's endogenous hormonal metabolism remains obscure (Bryant \& Cuming, 1993). Gibberellic acid has a well-established role in the mobilization of the seed's nutrient reserves in the cereals during germination, and the mobilization of reserves is clearly essential for successful seedling development in the longer term, but for the first 48 hours of germination, very little of the endosperm reserves is mobilized, and the nutrients utilized must therefore derive from the stores held within the embryo (principally lipids and storage proteins). When a seed is provided with water and oxygen at an appropriate temperature, water is taken up by imbibition in order to initiate the germination. Protein synthesis must play an important role in germination and early plant development. It is important for the growth of the embryonic axis and in the synthesis of hydrolytic enzymes as well as for the other cellular processes involved in the mobilization of food reserves. Germination can therefore be recognized as a catabolic stage because of this breakdown of reserves. Dry seeds contain residual mRNAs which were synthesized during embryogenesis. The mRNAs translated during early germination are soon replaced as germination progresses by the synthesis of new mRNA and of additional proteins. Not surprisingly, investigations of these new proteins have characterized many of them to be hydrolytic enzymes including amylases, proteases and lipases (for the mobilization of starch, protein and oil respectively) (Fincher, 1989; Bewley \& Black, 1985).

A close examination of the in vitro translation products from embryo mRNA sets isolated at different times of development has led to the identification of classes of genes expressed with characteristic patterns. The majority of genes are described to be produced constitutively, such as those encoding actins and tubulins (Dure, 1985), the remaining sets are expressed in a stage specific manner (Goldberg et al., 1989). Jendrisak (1980) reported that de novo mRNA synthesis was needed for resumption of growth in germinating wheat embryos. He suggested that the importance and significance of stored mRNA in the dry seed and its role in germination was minimal, since stored mRNA was by itself insufficient to allow for the resumption of germinative growth. As an imbibing seed undergoes the rapid transition from quiescence to vigorous metabolism many biochemical and physiological processes are activated. An obvious expectation is an increase in the expression of many different genes whose products provide for the higher levels of steadystate metabolic rate reached during this period (Caliskan et al., 2003). Whilst some of the biochemical events might be peculiar to this period, the majority would be expected to be related to normal growth-maintenance. Undoubtedly there are genes coding for proteins that control the activation of genes whose products provide for the higher steady-state 
metabolic rates seen. Moreover, there are probably a number of genes that code for proteins involved in the more complex developmental aspects of germination and seedling establishment. Seedling establishment needs the mobilization of stored reserves, involving such supporting tissues as the cotyledons and endosperm in dicotyledons seeds and the aleurone layer and endosperm in seeds of monocots. These tissues will undergo increases in expression of growth-maintenance genes, but there will be major activation of growth regulatory genes in accord with the role of these tissues in supporting germination and growth, e.g. the postgerminative production of hydrolytic enzymes by storage tissues.

An early event upon rehydration of seed tissues is an increase in protein synthesis and the proliferation of cellular organelles. The first consequence of imbibition may be an increase in ATP to an appropriate threshold level allowing this basic metabolic process to commence (Moreland, 1974). Axis germination would then proceed through an initial phase during which substrates and enzymes already present in the dry seed provide the required biochemical activity, to a final phase in which the primary interactants are mobilized substrates and proteins synthesized from newly transcribed mRNAs. After germination of both wheat and barley, the cells of the aleurone layer (the secretory cells that surround the nonliving starchy endosperm) synthesize several hydrolytic enzymes, including, characteristically, $\alpha$-amylase which increases its activity 100 -fold after germination. It was shown that activation of $\alpha$-amylase is under control of GA (gibberellic acid). In addition, a number of other hydrolytic activities are induced in the barley aleurone by GA, including nucleases, $\beta$-glucanases, and proteases (Bewley \& Marcus, 1990).

Although the induction of hydrolytic enzyme activities is essential during germination, plants need to synthesize some other proteins and enzymes which are required for a successful seedling development and autotrophic life. Typically, these are those associated with the establishment of photosynthetically competent tissues, and include all those structural proteins and enzymes found within the chloroplasts, in aeriel parts of the plant. However, although these gene products are needed for sustained growth, they can not be considered as germination-specific. A number of uncharacterized polypeptides have been shown to be uniquely associated with the onset of germination. One such protein has been isolated in 4 day old pea seedlings and it is called "C3 protein". This displays a shootspecific pattern of expression (de Vries et al., 1983). The absence of its mRNA in any other organs and also the insensitivity of its accumulation to illumination have indicated that the protein was not related to photosynthesis but rather is associated with shoot elongation. The gene for phytochrome is also stimulated in expression in germinated pea axes (Konomi et al., 1987). The amount of phytochrome mRNA and that of the mRNA for glutamine synthetase (glutamate-ammonia lyase EC 6.3.1.2) (clone 2A2; Datta et al., 1987), peaks shortly after the onset of increased embryo fresh weight, suggesting that these mRNAs can be regarded as functioning primarily in the maintenance of steady-state growth. Glutamine synthetase gene expression is also abundant in soybean seedling root tips (where the predominant activity is cell division and early elongation) and in rapidly growing soybean cell cultures (very little or no differentiation occurs), a conclusion again consistent with the notion that this gene is particularly involved in growth-maintenance, presumably through its role in nitrogen assimilation. By contrast, two other soybean seedling mRNAs have been identified (clones 4D7 and 2E2; Datta et al., 1987) which are not expressed in seedling root tips, nor in growing cells in culture, and thus were presumed to be involved in more subtle aspects of seedling development. Another defined mRNA, whose expression commences with the onset of germination, occurs in the wheat seedling. The product of this mRNA was 
called germin to indicate that it was associated in germinative growth (Grzelczak \& Lane, 1984). Germin (G) was not found in immature embryos or in mature, dry embryos before their hydration, nor was it found in mature wheat organs (Lane et al., 1992).

\subsection{The possible roles of germin gene products}

Germination is a critical period in plant development in which the rapid growth of the embryo is driven by water uptake. The water content of a mature wheat embryo in an ungerminated grain is less than $5 \%$; upon germination it rises to about $60 \%$ in less than 1 hour. Between 1 and 5 hours of imbibition there is no further in fresh mass or water content. A "secondary water uptake" phase then raises the water content from $60 \%$ to $85 \%$ by 24 hours postimbibition (Marcus, 1969). Biochemical analysis of wheat embryo germination indicates that there is only a limited accumulation of new gene products during germination (Thompson \& Lane, 1980) and until recently, just one had been observed to signal the onset of early plant development (Lane \& Tumaitis-Kennedy, 1981). The synthesis and translation of the mRNA for a soluble protein initially called " $\mathrm{g}$ " (Thompson \& Lane, 1980) and later called "germin" (Grzelczak \& Lane, 1984) was concomitant with the initiation of growth in germinating wheat embryos (Rahman et al., 1988). The appearance of germin mRNA was coincident with the secondary water uptake phase and the accumulation of the germin protein reached its highest level between $24-48$ hours postimbibition (about $\sim 40 \mathrm{ng} / \mathrm{embryo}$ in 40 hour germinated embryos (Grzelczak et al., 1985).

Germin was first detected in germinating cereals, but subsequently, germin-like proteins were also identified in a protist (Lane et al., 1991), dicotyledonous angiosperms (Michalowski \& Bohnert, 1992; Hofte et al., 1993; Delseny et al., 1994; Heintzen et al., 1994), and gymnosperms (Domon et al., 1995). Wheat germin is a relatively rare water-soluble glycoprotein (less than $0.1 \%$ of the mass of soluble proteins in germinating wheat embryos) which in homogenates exists as an oligomeric complex even which does not dissociate when analyzed by SDS-polyacrylamide gel electrophoresis (SDS-PAGE) unless boiled in the presence of the detergent (Grzelczak \& Lane, 1984). Three isoforms of germin have been defined. These are G, G' and $\Psi G$ (pseudogermin). The G and $G^{\prime}$ oligomers are water soluble, resistant to digestion by pepsin and to dissociation in aqueous SDS solutions at room temperature (Grzelczak \& Lane, 1983, 1984). Amino acid composition and sequencing indicate that $G$ and $G^{\prime}$ have the same apoprotein and differ only in that $G$ has two further Nacetylglucosamine units attached to the basic core of its N-glycans. (Jaikaran et al., 1990). Both forms of germin were defined as glycoproteins based on their positive Schiff reaction, which is a characteristic of glycoproteins as well as by the incorporation of radioactive glucosamine, mannose and fucose into the germin oligomer following labelling, in vivo. The carbohydrate content of germin is about $10 \%$ by weight (Lane et al., 1987; Jaikaran et al., 1990).

One of the most striking characteristics of germin is its resistance to proteolysis: it was found to be resistant to digestion by a broad range of proteases, including pepsin. By exploiting this property, milligram quantities of highly purified protein may be prepared from pepsinized supernatants of an homogenate, or simply from an aqueous wash fraction of germinated embryos, in a very short time (Grzelczak \& Lane, 1984). It seems possible that the oligosaccharide substituents in germin play a role in the remarkable stability of protein towards protease (Lane et al., 1987). In addition to the germination related germin isoforms $\left(\mathrm{G}\right.$ and $\mathrm{G}^{\prime}$ ), an antigenically related homotetrameric form of germin (pseudogermin - $\Psi G$ ) 
has also been detected, particularly in the cell walls of immature wheat embryos at a time when the maximum cellular enlargement associated with embryogenesis and maturation is occurring (20-25 dpa) (Caliskan et al., 2004). Unlike germin, pseudogermin is thermostable; the oligomer remains undissociated even when boiled in the presence of SDS, so long as non-reducing conditions (e.g. in the absence of mercaptoethanol) are maintained (Lane et al., 1992). Physicochemical studies indicated that germination-related germin (G) was a homopentamer and its oligomeric mass was calculated to be $\sim 130 \mathrm{KDal}$ when measured by three different methods. Therefore a molecular mass of 130/5 $=26 \mathrm{KDal}$ was calculated for the monomer (McCubbin et al., 1987).

A virtually full length germin cDNA was isolated (Rahman et al., 1988) and its polynucleotide sequence was determined (Dratewka-Kos et al., 1989). This germin cDNA has been used as a probe to indicate that germin is encoded by a multigene family which has $\sim 5$ copies on chromosome $4 \mathrm{~A}, \sim 3$ copies on chromosome $4 \mathrm{~B}$ and $\sim 9$ copies on chromosome $4 \mathrm{D}$ in hexaploid wheat. This cDNA was also used to screen a genomic wheat DNA library and the nucleotide sequences of a $2.8 \mathrm{kbp}$ fragment (gf-2.8) from one genomic clone, and of $3.8 \mathrm{kbp}$ fragment (gf-3.8) from another clone were determined. The protein coding-regions of these two genes are intronless and $87 \%$ identical (Lane et al., 1991). The association of germin isoforms with apoplast cause speculation that germin may have a role in embryospecific desiccation/hydration processes (Lane et al. 1991). It was observed that even if germin was purified free of other proteins, there was a selective association between germin and the highly substituted glucuronogalactoarabinoxylans (HS-GGAX) (Jaikaran et al., 1990) whose synthesis was reported to be closely associated with cell wall extension in cereals and grasses (Gibeaut \& Carpita, 1991). Upon this observation, it was suggested that germin-like oxalate oxidase might play a crucial role in early plant development by controlling integration of cell wall extension, for example by transporting extending wall material (e.g. HS-GGAX) into the cell wall to support extension and at the same time promoting crosslinking between wall polymers to restrict extension (Lane, 1994).

In gymnosperms, three germin-like proteins were discovered among the extracellular proteins produced by cells grown in liquid tissue culture. These proteins were found to be present in cultures which retained embryogenic potential, but to be absent in nonembryogenic cell lines. These proteins had high N-terminal amino acid sequence homology with other germins and were immunologically cross-reactive with an antiserum raised against the apo-protein component of cereal germin. Their molecular weight was about $\sim 26$ KDal. Pine germin-like proteins have not yet been shown to have oxalate oxidase activity (Domon et al., 1995). It was also demonstrated that wheat embryo callus induction by auxin is associated with a rapid accumulation of germin-like oxalate oxidase (Caliskan et al., 2004). Photoperiodic treatments of the short-day plant (SDP) Pharbitis nil seedling resulted in synthesis of a germin-like protein during darkness-induced flowering. This germin-like protein had a molecular mass of $22 \mathrm{KDal}$ in SDS-PAGE analyses, and it reached the highest level of accumulation after the critical length of the dark period $(\sim 10$ hours after the light was turned off). The cotyledons and leaves, known to be the two major organs that perceive the photoperiod and produce the floral stimulus, were the only expression sites for this protein. Sequence analysis showed that the Pharbitis nil germin-like protein shared the highest homology a germin-like protein in another dicotyledonous plant, Sinapus alba (white mustard). No oxalate oxidase activity was found for Pharbitis nil germin-like protein (Ono et al., 1996). 
The similarities between wheat germin and the barley germin-like polypeptides may imply that both of these proteins have some protective function during early plant development. In wheat embryos, germin increases significantly during seed germination. Based on the increase in carbohydrate synthesis during germination and the presence of adventitious arabinoxylans in wheat germin preparations this has prompted speculation that germin could have a function in cell wall expansion (Jaikaran et al., 1990). The identification of cereal germins as oxalate oxidases (Dumas et al., 1993; Lane et al., 1993) has caused us to modify this view (Caliskan \& Cuming, 1998). The principal product of the degradation of oxalic acid is hydrogen peroxide which is a highly reactive compound known to be involved in several metabolic processes in higher plants. The discovery of its oxalate oxidase activity instantly suggested several specific ways in which germin might function. Specifically, linkage of the developmental appearance of cell wall bound germin (Lane et al., 1992) to oxalate degradation suggests that germin might have a role in cell wall reinforcement by producing $\mathrm{Ca}^{++}$and $\mathrm{H}_{2} \mathrm{O}_{2}$ for pectic cross-linking and peroxidase mediated cross-linking of cell wall polymers respectively. Proteins could be cross-linked through tyrosine side-chains, lignin via $-\mathrm{OH}$ groups and carbohydrates via - $\mathrm{COOH}$ groups (Cassab \& Varner, 1988; Showalter, 1993). The anchorage of at least a proportion of the germin-like oxalate oxidase in the cell wall with GGAX oligomers also implicates it in the cross-linking of these components within the cell wall matrix; notably, arabinoxylan comprises a substantial fraction of monocotyledonous cell walls, in which the oxalate oxidase activity of germin-like proteins is characteristic. Although germin-like proteins have been identified in dicotyedonous plants, these, for the most part, have not been shown to possess oxalate oxidase activity. An exception to this is the oxalate oxidase of Beta vulgaris, which has been found to be germin-like in its properties (a protease-resistant SDS-stable oligomer): notably, the cell walls of this species, and other members of the Chenopodiaceae, are more "cereal-like" than "typically dicotyledonous", being enriched in arabinoxylan content (Bacic et al., 1988). Germin synthesis also appears to be auxin responsive (Berna \& Bernier, 1997). Typically, auxins stimulate cell wall loosening and bring about cell wall expansion. On the other hand, germin (oxalate oxidase activity) produces hydrogen peroxide which is believed to be required for the peroxidase mediated cross-linking reactions in the cell wall. Thus, it was suggested that germin synthesis might be associated with both initiation and termination of cell wall expansion in early plant development (Lane, 1994).

Germin-like oxalate oxidase is also a pathogen inducible enzyme (Zhang et al., 1995; Dumas et al. 1995; Hurkman \& Tanaka, 1996b). The production of $\mathrm{H}_{2} \mathrm{O}_{2}$ (the "oxidative burst") is the primary response of some higher plants to pathogen (Erisyphe graminis) infection. $\mathrm{H}_{2} \mathrm{O}_{2}$ can be implicated in the development, differentiation, vascularization, defence and signalling processes of higher plants. The action of oxalate oxidase, in generating $\mathrm{H}_{2} \mathrm{O}_{2}$, could be an especially potent defence mechanism. The pathogen-responsive oxalate oxidase was different from both the commercially available barley root oxalate oxidase, and barley salt stress-induced root oxalate oxidase in its molecular weight. Commercial oxalate oxidase was reported, variably, to have a molecular mass $80 \mathrm{KDal}$ in $8 \%$ SDS-PAGE (or, Dumas et al. (1995) report $100 \mathrm{KDal}$ ) whereas the pathogen-related oxalate oxidase is $100 \mathrm{KDal}$ - $95 \mathrm{KDal}$. This may therefore represent a specific, individual member of the germin gene family. In a parallel study of transcripts induced in response to Erisyphe infection, two novel germin-like sequences were identified as pathogen-responsive (Zhang et al., 1995). 
Dumas et al., (1995) demonstrated an increase in the activity of germin-like oxalate oxidase in association with the response of barley to Erisyphe graminis. In normally growing seedlings, oxalate oxidase activity was detected in a tissue specific manner in 3 day germinated seed (in roots) and 10 day germinated seedlings (in the residual coleorhiza). These activities were demonstrated to be associated with a germin-like protein by immunoblotting using anti-germin antibody. In 10 day old seedling coleoptiles a $26 \mathrm{KDal}$ polypeptide reacted with anti-germin serum but appeared to lack oxalate oxidase activity. This suggested that an inactive form of oxalate oxidase could accumulate. On infection by the fungus, oxalate oxidase was induced in barley leaves (5 day), especially along the vascular bundles. This suggested that oxalate oxidase belonged to a class of proteins that responds to pathogen attack. The production of $\mathrm{H}_{2} \mathrm{O}_{2}$ by oxalate oxidase might be significant in two ways: (1) By further enhancement of the defence response (through induction of further plant defence responses as a signalling molecule), (2) Through $\mathrm{H}_{2} \mathrm{O}_{2}$ being used as a substrate by peroxidase to mediate cross-linking of cell wall polymers (e.g. lignin) in the hypersensitive response, causing the sealing of infected lesions (Dumas et al., 1995).

Similarly, in wheat, germin mRNA, germin and oxalate oxidase activity were induced in leaves of wheat upon infection with Erisyphe (6 day old seedling +2, 4, 6, 8 days after inoculation). The control leaves at the same age gave negative results. An increase in expression of peroxidase was also detected. These results reinforce the suggestions that germin activity has a role in plant defence through the local production of $\mathrm{H}_{2} \mathrm{O}_{2}$ for the hypersensitive defence response (Hurkman \& Tanaka, 1996b). This suggests that the genes encoding germin-like oxalate oxidase might have potential in transgenic approaches to plant defence. Another peroxide generating enzyme, a fungal glucose oxidase, has been shown to enhance the resistance of transformed plants to fungal infection, when introduced as a transgene (Wu et al., 1995). In experiments designed to protect Brassica napus plants from the oxalate secreting fungus, Sclerotinia transgenic oilseed rape plants, transformed with barley oxalate oxidase, were found to express a $25 \mathrm{kDal}$ protein reactive with anti-germin antiserum and to express oxalate oxidase activity which protected plants against potentially toxic applications of oxalic acid (Thompson et al., 1995). In a current study, 36 expressed sequence tags (ESTs) encoding GLPs from peanut (Arachis hypogaea L.) were identified. The purified AhGLP2 has displayed superoxide dismutase (SOD) activity in enzymatic assay, but not oxalate oxidase activity. It was reported that the SOD activity of AhGLP2 was stable up to $70 \mathrm{~A}{ }^{\circ} \mathrm{C}$ and resistant to hydrogen peroxide, suggesting that AhGLP2 might be a manganese-containing SOD and likely protects peanut plants from reactive oxygen metabolites (Chen et al., 2011). The rice germin-like protein (OsGLP1) being a cell wallassociated protein involved in disease resistance also revealed to possess superoxide dismutase (SOD) activity as recognized by heterologous expression in tobacco (Banerjee et al., 2010).

It was discovered that both germins and spherulins had statistically significant sequence similarity with plant seed storage globulin domains. The germins were clearly related both to seed globulins (Baumlein et al., 1995) and spherulins (Lane et al., 1991). On the basis of these similarities, it has been proposed there is a superfamily (groups of gene families encoding structurally related but functionally distinct proteins) of related genes encoding vicilins, legumins, SBPs (sucrose-binding proteins), germins and spherulins. SBPs are proteins associated with the plasma membrane and which have a role in sucrose transport, and it is known that spherulins have a function in the cellular desiccation process, including 
osmotic regulation. It has been suggested that sucrose may serve as one of the principal agents in the acquisition of desiccation tolerance in seeds and other plant tissues, where the role of disaccharides in the assumption of a "glassy state" by the cytosol has been inferred (Leopold et al., 1992). The legumin-like 11S and the vicilin-like $7 S$ seed proteins are synthesized and accumulated during seed maturation, and are stored in protein bodies in mature seeds. In the timing of their accumulation, and their regulation by agents such as abscisic acid, they are at least associated with the acquisition of desiccation tolerance by seeds, which occur during the maturation phase of seed development (Braun et al., 1996).

\subsection{The enzymatic activity of germins: oxalate oxidase}

Oxalic acid is one of the strongest organic acids with pKa values of 1.3 and 4.3 (Lane, 1994). Oxalic acid has a wide variety of industrial and household applications for instance it is used as an analytical reagent. Oxalic acid is also a constituent of cleaning solutions for removing paint, varnish, rust and ink stains as well as being used extensively in laundries as a scouring agent to remove excess alkalinity remaining in washed fabrics. It is also used for cleaning or bleaching wood and straw, as a chrome stripper and as a bleach in leather manufacture.

In plants, the highest oxalate concentrations commonly occur in the leaves and the lowest in roots. Meanwhile, the oxalate content of plants can vary according to their age, the season, the climate and the type of soil. Wide variations can occur in the oxalate content of plants. In some plants, such as rhubarb, oxalate content tends to increase as the plants mature, whereas, in other plants, e.g. spinach, sugar beet leaves, oranges, bananas, there is a large increase in oxalate content during the early stages of development, followed by a decrease as the plants mature.

Although the origin of oxalic acid in plants is controversy, the early studies on plant organic acids, including oxalic acid, yielded evidence that the production of these acids was related to photosynthesis and carbohydrate metabolism. Myers (1947) noted that oxalate concentration in rhubarb leaves increased in parallel with the growing seasons, being correlated with the seasons of most active photosynthesis. Later, experiments on rhubarb and Begonia indicated that oxalic acid was not a direct product of photosynthesis but it was synthesized from precursors synthesized in the photosynthetic pathway (Stuta \& Burris, 1951; Tavant, 1967).

Now, it is well known that oxalic acid is synthesized via several major pathways. Although glyoxylate and L-ascorbic acid appear to be the major precursors of oxalic acid in plants (Davies \& Asker, 1983; Yang \& Loewus, 1975), some other possible pathways have been reported. Glucose, acetate and some acids of the tricarboxylic acid cycle were determined to be involved in oxalate biosynthesis in red beet roots and young spinach leaves (Chang \& Beevers, 1968). Moreover, glycolic and isocitric acids (Millerd et al., 1963), oxaloacetic acid (Chang \& Beevers, 1968) are known to donate carbon to oxalic acid in plants. The relative significance of these metabolites as precursors of oxalic acid has not been established (Wagner, 1981).

The enzymes involved in the synthesis and degradation of oxalic acid are of interest. In lettuce, two enzymes identified to have a role in the oxidation of glycolate and glyoxylate to oxalic acid were lactate dehydrogenase and glycolate oxidase (Davies \& Asker, 1983). Since oxalic acid could be formed from several precursors, there is no clear evidence of its synthesis and deposition site. However, it was observed that the primary site of deposition of oxalic acid formed from L-ascorbic acid was the vacuole in barley which is a low level oxalic acid accumulator (Wagner, 1981). 
Most of the plants and animals produce oxalic acid, and it is of interest that they share some common pathways of oxalic acid synthesis. Oxalate may be present in the tissues as the free oxalic acid, as soluble sodium and potassium salts or as insoluble calcium oxalate crystals. Calcium oxalate crystal formation in animals is generally considered to be pathological. The pathological role of oxalic acid in the formation of urinary stones in animals and humans has been known since the early 18th century. For example, excess consumption of oxalaterich foods leads to hyperoxaluria which is recognized as a key risk factor for calcium oxalate stone formation (Sharma et al., 1991). Furthermore, there is evidence that high ascorbic acid intake increases urinary oxalate levels which could lead to the formation of calcium oxalate stones in the kidneys and other regions of the urinary system (Roth \& Breitenfield, 1977). Oxalic acid is regarded as an undesirable component of our food not only because it raises the risk of urinary stones but also because it sequesters calcium, which is one of the essential ions, as insoluble calcium oxalate. The toxicology of oxalic acid in humans was reviewed by several researchers (Polson \& Tattersall, 1959; Hodgkinson, 1977). In medicine, the knowledge of the oxalate concentration in blood and other body fluids can be very important in certain clinical situations such as primary hyperoxaluria (Pertrarulo et al., 1990). Various methods have been formulated for the assay of oxalate from different sources, for instance, gas-liquid chromatography, ion chromatography, high performance liquid chromatography, mass spectrometry and enzymatic determination methods have all been developed. Of these, the oxalate oxidase activity-based determination of oxalate has become very popular and is used widely because of its simplicity, specificity and sensitivity (Pundir et al., 1985).

Oxalic acid has usually been seen as an inert end product of metabolism and only plants have been reported to be able to metabolize oxalic acid and oxalates. However, recent studies indicate that the levels of oxalate are too high for the substance to only be an endproduct of metabolism in animals (Emsley, 1994). Therefore, it has been suggested that there could be an oxalate oxidase pathway in animals which uses oxalate to produce $\mathrm{H}_{2} \mathrm{O}_{2}$, which could than be used to promote a "burst" of phagocytes: cells that engulf and break down foreign particles, cell debris and disease-producing microorganisms. Unlike animals, plants are highly tolerant of oxalic acid and oxalates. Oxalic acid and oxalates have been detected in varying quantities in all parts of most plants' leaves, leaf stalks, flowers, tubers and roots (Srivastava \& Krishnan, 1959). It is well established that plants are capable of metabolizing oxalate by observing fluctuations in oxalate concentrations under certain conditions (Vincent \& Harry, 1980), and enzymes degrading oxalic acid have been detected in numerous plants. Several functions have been proposed for the presence of oxalic acid in plants. It has been implied that oxalic acid might be related to ionic balance, since it can combine with various plant ions to form soluble or insoluble compounds. It was suggested that oxalate synthesis occurred to balance the excess of inorganic cations (represented by $\mathrm{K}^{+}$, $\mathrm{Na}^{+}, \mathrm{NH}_{4}{ }^{+}, \mathrm{Ca}^{++}$and $\mathrm{Mg}^{++}$) over anions (represented by $\mathrm{NO}_{3}{ }^{-}, \mathrm{Cl}^{-}, \mathrm{H}_{2} \mathrm{PO}_{4}^{-}, \mathrm{SO}_{4}^{-2}$ ) normally present in the plant - the ability of nitrate ions and chloride ions to inhibit oxalic acid oxidase activity in Beta vulgaris results in an accumulation of oxalate.

Calcium oxalate crystals were amongst the first objects observed in plants in the early days of light microscopy in the late 17th century (Lane, 1994). Insoluble calcium oxalate formation enables plants to control the concentration both of ionically active oxalic acid and calcium. Both of these molecules might have a toxic effect when accumulating in excess quantities. Thus plants could induce calcium oxalate crystal formation to remove excess oxalic acid or calcium. Although calcium is essential to biological growth and development, free calcium 
at high concentrations is toxic to cells. So it was suggested that calcium oxalate precipitation serves to sequester excess calcium and remove it from active metabolism (Webb et al., 1995). The rapid induction of calcium oxalate crystal formation by calcium in Lemna plants suggests that the crystals may serve as a storage form for calcium for future needs (Hepher \& Wayne, 1985). Further support for this came from the observation that in some plants the crystals appear to be dissolved during calcium deficient conditions, presumably to supply calcium for growth and cell maintenance (Franceschi, 1989). Calcium is required for the activation and/or stabilization of certain enzymes; for example plant cells need calcium to release peroxidases which are related to the control of cell elongation since they can rigidify walls by their cross-linking activity and their ability to participate in the formation of lignin. Thus, for this role they are under the control of cellular calcium levels (Sticher et al., 1981). One of the major roles of calcium in plant cells is its action in the formation of the middle lamella where $\mathrm{Ca}^{2+}$ ions form stabilising ionic bridges between pectin chains. Although it has been suggested that calcium oxalate crystals are a means of detoxifying excess oxalic acid, the fact that many plants are able to retain high concentrations of soluble and free oxalic acid within their vacuoles indicates that oxalic acid may not be particularly toxic to plant tissues. However, accumulation of oxalic acid may have some toxic consequences (for example in causing osmotic problems and destabilization of cells), unless it is readily metabolized (Raven \& Smith, 1976).

It is well known that certain plant pathogenic fungi secrete oxalic acid as part of the process for invasion of plant tissues. For example, Sclerotium rolfsii Sacc., a fungus, causes diseases of plants in nearly 100 plant families. Considerable quantities of oxalate were detected in infected but not in healthy tissues. Oxalic acid produced by this pathogenic fungus played an essential role in its pathogenic capabilities (Maxwell \& Bateman, 1968). Another pathogenic fungus infecting a wide range of plant species is Sclerotinia sclerotiorum. During infection, the fungus produces high levels of a necrosis phytotoxin identified as oxalic acid (Noyes \& Hancock, 1981). The role of oxalic acid in the pathogenicity process is still unclear. However, oxalic acid may have a number of functions in the infection process including chelating calcium from the cell wall thus making the pectic fraction more available to fungal hydrolases, and providing an acid $\mathrm{pH}$ needed for maximum activity of the wall degrading enzymes released by the pathogenic fungus (Keates et al., 1996). Furthermore, it was suggested that oxalic acid produced by fungi played a key role in lignin biodegradation through its stimulation of lignin-degrading enzymatic activities (e.g. Mn-peroxidase activity) (Kuan \& Tien, 1993). One part of the plant defence response to this may be the production of oxalate oxidase which is an oxalic acid degrading enzyme. A second response would be the induction of deposition of oxalic acid in the form of soluble or insoluble salt.

Oxalic acid and its salts, oxalates, are widely distributed within the cells and cell walls of plants and probably they play an important role in tissue metabolism. There are two possible enzymatic reactions for the degradation of oxalate in plants: (1) decarboxylation by oxalate decarboxylase (oxalate carboxy-lyase, EC 4.1.1.2) which catalyzes conversion of one mole of oxalate to one mole of $\mathrm{CO}_{2}$ and formate, (2) oxidation by oxalate oxidase. Oxalate oxidation has been found to occur in fungi, mosses and higher plants, but the biological significance of oxalate oxidation is not yet clear. The discovery that germin, a protein marker of early plant development, is an oxalate oxidase suggested that oxalate oxidase, the enzymatic formation of $\mathrm{H}_{2} \mathrm{O}_{2}$, and $\mathrm{Ca}^{++}$release from poorly soluble calcium oxalate might play an important role in metabolic regulation, particularly in cell wall modification during germination and seedling development. 
Oxalate oxidase is an oxidoreductase (oxalate: oxygen oxidoreductase EC 1.2.3.4) which catalyzes the formation of one mole of $\mathrm{H}_{2} \mathrm{O}_{2}$ and two moles of $\mathrm{CO}_{2}$ from one mole of oxalate and aerobic oxygen. Oxalate oxidase has been found in Pseudomonas sp. OX-53 (Koyama, 1988), Tilletia controversa (Vaisey et al., 1961), banana peel (Raghwan \& Devasagayam, 1985), mosses (Laker et al., 1980), Bougainvillea leaves (Srivastava \& Krishnan, 1962), barley seedlings and roots (Chiriboga, 1966; Pietta et al., 1982), spinach, beet stem and leaves (Obzansky \& Richardson, 1983; Leek et al., 1972), and leaves and roots of CSH-1 and CSH-5 varieties of grain sorghum (Pundir \& Nath, 1984; Pundir \& Kuchhal, 1989).

An oxalate oxidase was purified from sorghum leaves with a molecular weight of $62 \mathrm{kDal}$ and $\mathrm{pH}$ optimum of 4.3 . This enzyme had maximum activity at $40{ }^{\circ} \mathrm{C}$ and it was insensitive to $\mathrm{Na}^{+}$. This property made it well suited for medical diagnostic use in the detection of oxalate in urine - the principal cause of kidney stone formation. The enzyme was suggested to be a flavoprotein on the basis of stimulation of its activity by FAD. However, neither the barley oxalate oxidase nor that of Pseudomonas sp. OX-53 was classified as flavoproteins (Pundir, 1991).

Of the other oxalate oxidases purified from plant sources, that from grain sorghum leaves (Sorghum vulgare L hybrid CSH-5) (Kuchhal et al., 1993) was active in a range of $\mathrm{pH}$ from 46, with an optimum of $\mathrm{pH}: 5$ and optimal temperature of $40^{\circ} \mathrm{C}$. The optimum $\mathrm{pH}$ for barley oxalate oxidase was $\mathrm{pH}: 3.2$, and for mosses $\mathrm{pH}$ : 4, whilst the bacterial (Pseudomonas) enzyme was maximally active at $\mathrm{pH}$ : 4.8. The enzyme purified from grain sorghum leaves was heat sensitive, as it lost $80 \%$ of its activity when heated at $80{ }^{\circ} \mathrm{C}$ for 3 min whilst the inhibition of the enzyme by EDTA, and its stimulation by metal ions $\left(\mathrm{Cu}^{++}, \mathrm{Mg}^{++}\right)$, led it to be subsequently classified as a metalloprotein and not a flavoprotein. Both the enzymatic activity and oxalate content showed progressive decrease with the advance of germination in sorghum. These data suggested that the high enzyme activity during initial growth was required for degradation of endogenous oxalate to form $\mathrm{H}_{2} \mathrm{O}_{2}$ which might play an important role in cellular regulation, such as glucose transport, glucose incorporation into glycogen, lipid synthesis, and release of $\mathrm{Ca}^{++}$(Kuchhal et al., 1993).

The oxalate oxidase purified from leaves of grain sorghum hybrid CSH-5 was reported to have a molecular mass of $120 \mathrm{KDal}$ and to be composed of $62 \mathrm{KDal}$ monomeric subunits, unlike the enzymes purified from moss, barley, and banana peel, it was unaffected by $\mathrm{Cl}^{-}$, in the physiological concentration range, which made it particularly suitable for urinary diagnostic tests, since the removal of $\mathrm{Cl}^{-}$from urine, prior to oxalate assays was not required (Satyapal \& Pundir, 1993). More recently, an oxalate oxidase has been purified from beet stems (Beta vulgaris L.) (Azarashvili et al., 1995). When the activity of this enzyme was determined as a function of $\mathrm{pH}$ and temperature, the optimal conditions were found to be at $\mathrm{pH}: 4$ and $30{ }^{\circ} \mathrm{C}$. This enzyme has been incorporated into an automated method for determination of urinary oxalate - a rapid ( 3 hours) and reliable procedure based on the measurement of $\mathrm{H}_{2} \mathrm{O}_{2}$ produced by oxidation of oxalate. The chromogen MBTH-DMA was used to measure the hydrogen peroxide produced (Obzansky \& Richardson, 1983). Nitrate ions (at concentrations as low as $5 \times 10-5 \mathrm{M}$ ) was identified as the sole factor in crude beet extracts responsible for the inhibition of oxalate oxidase activity in vitro (Meeuse \& Campbell, 1959). This would lead to accumulation of oxalate in cells.

Barley seedling oxalate oxidase was purified by Sugiura et al. (1979). It was originally reported to have a monomeric molecular mass of $75 \mathrm{KDal}$ and to assemble as a homodimer of $150 \mathrm{KDal}$. The optimal $\mathrm{pH}$ and temperature were found to be 3.2 and $37^{\circ} \mathrm{C}$, respectively. The enzyme was found to be extremely stable at temperatures up to $70^{\circ} \mathrm{C}$ and to be strongly 
inhibited by 2-mercaptoethanol and halogen ions $\left(\mathrm{Cl}^{-}, \mathrm{F}^{-}\right)$. This enzyme appeared to differ in its properties from the sorghum leaf enzyme, which in addition to its different $\mathrm{pH}$ and temperature optima, and molecular mass, was not inhibited by halogen ions (Satyapal \& Pundir, 1993).

Oxalate oxidase activity in plants may vary between species, and differ between organs and tissues of a plant even though these may have similar oxalate contents. For example, a close examination of germinated cereal embryos indicated that there are only modest differences between the oxalate contents of different varieties. However, there may be gross differences between their oxalate oxidase activities. For example, cold-tolerant maize (C0255) contains 20 fold higher levels of oxalate oxidase activity than cold-sensitive maize (C0286), whilst in 6 day germinated wheat seedlings, the coleoptile and leaf have the similar oxalate content but the coleoptile has $\sim 16$ times higher levels of oxalate oxidase activity than the leaves (Lane, 2000).

Analysis of beet shows that the oxalate content of this dicotyledonous plant is $\sim 10$-fold greater than that determined in wheat, but that the oxalate oxidase/oxalate ratio is 100 -fold smaller than for hexaploid wheat. Beet oxalate oxidase shares several properties with the wheat enzyme: typically the "germin-like" characteristic of resistance to SDS-denaturation, allowing its activity to be determined directly in SDS-PAGE gels. However it was sufficiently immunologically similar to be recognized by wheat anti-germin in Westernblots. By contrast, the sorghum oxalate oxidase, although derived from a monocotyledonous source did not have "germin-like" stability, but it did react weakly with the anti-serum raised against wheat germin (Lane 2000).

\subsection{The expression of germin genes under salt stress}

Although there are plenty of organisms need salt to carry out their life (Ozcan et al., 2006, 2007) excessive salt is a stress factor for most of the living beings. Salt stress is also an important agricultural problem, particularly since the majority of crop plants have low salt tolerance. The response of plants to salt stress is a complex phenomenon that involves biochemical and physiological processes as well as morphological and developmental changes (Flowers et al., 1977; Greenway \& Munns, 1980). The identification of genes whose expression enables plants to adapt to or tolerate to salt stress is essential for breeding programs, but little is known about the genetic mechanisms for salt tolerance. One approach in clarifying the molecular mechanisms involved in salt stress is to identify the genes whose levels change as a result of salt stress.

Isolation and examination of the two germin genomic clones (Rahman et al., 1988) and the determination of the predicted amino acid sequences have revealed high homology with spherulin 1a/1b proteins of the slime mould Physarum polycephalum (Lane et al., 1991). The synthesis of these proteins occurs during spherulation: a transition leading to developmental arrest imposed by environmental conditions such as osmotic stress and starvation (Bernier et al., 1987), this similarity led to the suggestion that another possible function for germin might be related to the changing osmotic properties of cells. In support of this notion, synthesis of germin-like proteins was discovered to be altered upon salt stress in barley (Hurkman et al., 1991) and in the halophytic "ice plant", Mesembryanthemum crystallinum, (Michalowski \& Bohnert, 1992). In salt-stressed barley, these proteins, like wheat germin, were resistant to protease and were glycosylated and heat stable. They were detected in barley roots (but not in tips) and coleoptiles but not leaf of 6 day seedlings. Their synthesis increased in roots upon salt stress, but decreased in coleoptiles. On the other hand, 
it was observed that the synthesis of a germin-like protein in the ice plant declined after salt stress (Michalowski \& Bohnert, 1992). Thus, these different studies implied that germin might represent a family of proteins of which individual members may have different biochemical functions related to changes of the osmotic properties of the cell.

Experiments based on the extraction of mRNA from different organs suggest that wheat and barley have different spatial distributions of germin mRNA expression (Hurkman \& Tanaka, 1996a). The vascular transition region was reported to contain the highest levels of germin mRNA in wheat, whereas roots displayed the highest germin expression levels in barley seedling. It was additionally observed that salt stress caused an increase in germin mRNA in roots at an early developmental stage ( 3 days on $0.2 \mathrm{M} \mathrm{NaCl}$ ), whereas, in the whole seedling, salt stress cause the "normal" expression of germin to be prolonged, relative to that in control seedlings. Overall, it was concluded that germin gene expression in barley seedlings was developmentally regulated in a tissue-specific manner, and also, potentially, by various plant hormones (IAA, ABA). Interestingly, it was discovered that a decline in germin expression occurred after 3 days in control seedlings and after 4 days in stressed seedlings - in both case seedlings were at a similar developmental stage, as assessed by seedling weight (approximately $25 \mathrm{mg}$ in each treatment). Thus one interpretation of the experimental data is that $\mathrm{NaCl}$ treatment prolongs germin gene expression for an additional 1 day indirectly, through a slowing of seedling growth (Hurkman \& Tanaka 1996a).

Among the salt stress responsive gene products, germin and germin-like proteins (GLP) suggested to be a member of "superfamily" which comprises various growth-related genes were identified (Caliskan, 1997; Hurkman et al., 1989). Cereal germin proteins have strong oxalate oxidase activity (Lane et al., 1993), an activity that produces one mole of $\mathrm{H}_{2} \mathrm{O}_{2}$ and two moles of $\mathrm{CO}_{2}$ from degradation of oxalic acid. It is reported that $\mathrm{H}_{2} \mathrm{O}_{2}$ might act as a signaling molecule at low concentration (Luthell, 1993) or a component of cell wall modifications at high concentrations (Showalter, 1993). Another germin-like protein isolated from the cells of a moss, Barbula unguiculata, was shown to have manganese superoxide dismutase activity (Yamahara et al., 1999). Germin genes and proteins have been shown to be associated with various aspects of plant development (Caliskan, 2000; Lane, 2002) such as defense system (Berna and Bernier, 1999; Donaldson et al. 2001), embryonic development (Caliskan, 2001), photoperiodic oscillations (Ono et al. 1996), and hormonal stimuli (Berna and Bernier, 1997). The accumulation of germin gene products in wheat and barley seedlings in the presence of $\mathrm{NaCl}$ was analyzed previously, but little is known about the possible role of germin gene products during salt stress (Hurkman et al., 1991; 1994; Hurkman \& Tanaka, 1996a; Berna \& Bernier, 1999).

Germin and germin-like proteins are suggested to be salt-responsive gene products and their response to salt stress seems to be various. For example, accumulation of germin mRNA is up-regulated during the growth of germinating barley seedlings in the presence of $\mathrm{NaCl}$ (Hurkman \& Tanaka, 1996a). In contrast, it is reported that in ice plant (Mesembryanthemum crystallinum) the synthesis of GLPs declined after salt stress (Michalowski and Bohnert, 1992). On the other hand, it was reported that in wheat seedlings germin synthesis was remained unchanged in the presence of $\mathrm{NaCl}$ (Berna \& Bernier, 1999; Caliskan, 2009). The addition of $\mathrm{NaCl}$ to the cells of moss, Barbula unguiculata, during the logarithmic phase increased both the BuGLP mRNA levels and total SOD activity of BuGLP, but decreased the SOD activity bound to the cell wall due to release of most of the SOD activity into the medium. On the other hand, the addition of $\mathrm{NaCl}$ to the cells during the 
stationary phase hardly affected $B u G L P$ mRNA levels or SOD activity levels bound to the cell wall. These results suggest that the induction of BuGLP gene by salt stress is caused by dissociation of BuGLP protein from the cell wall into the medium in the cells during the logarithmic phase (Nakata et al., 2002).

In situ RNA hybridization is one of the most powerful techniques developed for localizing the expression site of particular gene products at the cell, tissue and organ levels. This method is particularly useful in understanding the function of specific gene products in particular tissues and the relation between tissue function and its localization in the whole structure of an organ (Ranjhan et al., 1992). This technique was employed for analyzing the possible germin functions and it was shown that germin mRNAs synthesized in the cells of coleorrhiza in wheat seedlings and it was considered that the enzymatic activity of germin, oxalate oxidase, might play an important role in metabolic regulation, particularly in cell wall modification during germination and seedling development (Caliskan \& Cuming, 1998). It is well known that stress factors alter the synthesis of gene expression. Indeed, upon salt stress the localization pattern of germin gene expression was changed (Caliskan, 2009). It is shown that although the water grown embryos and salt stress grown embryos accumulate the similar amount of germin mRNAs, the synthesis site of germin mRNAs are completely different from each other. In germinating wheat embryos the salt stress somehow caused germin mRNAs to be synthesized in coleoptile instead of coleorrhiza cells (Caliskan, 2009). It is possible to envisage that an explanation for the reasons of this shift will help us to have a better understanding of stress physiology of plants.

\section{Conclusion}

Although germin and germin-like proteins have been studied extensively since the 1980s, their biological importance and functions remain confusing. Furthermore, germin, germinlike proteins and oxalate oxidase have been found in a broad range of various plant species under different circumstances, and related with different aspects of plant development. For example, germin-like protein and oxalate oxidase enzyme activity have been identified in plants in relation to salt stress, pathogen infection, photoperiodic oscillations, germination and embryogenesis. It has also reported that germin and germin-like proteins and oxalate oxidase are responsive to various plant growth regulators such as auxin and abscisic acid. Germin-like oxalate oxidase therefore seems to fulfil some crucial functions in plants. In addition to these properties, recently it was suggested that germins and various other proteins which are involved in early plant development might belong to an evolutionarily ancient superfamily: cupin superfamily (Dunwell et al., 2000; 2008).

\section{Acknowledgment}

I would like to thank for the contribution of Turkish High Education Board, University of Leeds (UK) and Mustafa Kemal University (Turkey) during my studies.

\section{References}

Azarashvili, T.S., Evtodienko, V., Yu. \& Kudzina, L., Yu (1996). Isolation, purification, and kinetic properties of oxalate oxidase (EC 1.2.3.4) from beet shoots. Russian J. Plant Physiol. 43(2), 169-173 
Bacic, A., Harris, P.J. \& Stone, B.A. (1988). Structure and function of plant cell walls. In: The biochemistry of plants, a comprehensive treatise, J. Preiss (Ed.), volume 14, 297-358, Academic Press Inc. London

Banerjee, J., Das, N., Dey, P. \& Maiti M.K. (2010). Transgenically expressed rice germin-like protein1 in tobacco causes hyper-accumulation of $\mathrm{H}_{2} \mathrm{O}_{2}$ and reinforcement of the cell wall components. Biochem. Biophys. Res. Commun. 402, 637-643

Baumlein, H., Braun, H., Kakhovskaya, I.A. \& Shutov, A.D. (1995). Seed storage proteins of spermatophytes share a common ancestor with desiccation proteins of fungi. J. Mol. Evol. 41, 1070-1075

Bernier, F., Lemieux, G. \& Pallotta, D. (1987). Gene families encode the major encystmentspecific proteins of Physarum polycephalum plasmodia. Gene 59, 265-277

Berna, A. \& Bernier, F. (1997). Regulated expression of a wheat germin gene in tobacco: oxalate oxidase activity and apoplastic localization of the heterologous protein. Plant Mol. Biol. 33, 417-429

Berna, A. \& Bernier, F. (1999). Regulation by biotic and abiotic stress of a wheat germin gene encoding oxalate oxidase, $\mathrm{a}_{2} \mathrm{O}_{2}$-producing enzyme. Plant Mol. Biol. 39, 539-549

Bewley, J.D. \& Marcus, A. (1990). Gene expression in seed development and germination. Prog. Nucl. Acid Res. 38, 165-193

Bewley, J.D. (1997). Seed germination and dormancy. The Plant Cell 9, 1055-1066

Braun, H., Czihal, A., Shutov, A.D. \& Baumlein, H. (1996). A vicilin-like seed protein of cycads: similarity to sucrose-binding proteins. Plant Mol. Biology 31, 35-44, 1996

Bryant, J.A. \& Cuming, A.C. (1993). Molecular control of development. In: Plant Biochemistry and Molecular Biology, P.J. Lea \& R.C. Leegood (Eds.), 241-273. John Wiley \& Sons Ltd. England

Butler, W.M. \& Cuming, A.C. (1993). Differential molecular responses to abscisic acid and osmatic stress in viviparous maize embryos. Planta 189, 47-54

Caliskan, M. (1997). Temporal and spatial analysis of germin synthesis. University of Leeds, $\mathrm{PhD}$ Thesis, Leeds UK

Caliskan, M. \& Cuming A.C. (1998). Spatial specificity of $\mathrm{H}_{2} \mathrm{O}_{2}$-generating oxalate oxidase gene expression during wheat embryo development. Plant J. 15, 165-171

Caliskan, M. (2000). Germin, an oxalate oxidase, has a function in many aspects of plant life. Tr. J. Biol. 24, 717-724

Caliskan, M., Bashiardes, S., Ozcan, B. \& Cuming, A.C. (2003). Isolation and localization of new germination-related sequences from wheat embryos. J. Biochem. Mol. Bio. 36(6), 580-585

Caliskan, M., Turet-Sayin, M., Turan, C. \& Cuming, A. (2004). Identification of germin isoforms in wheat callus. Cereal Res. Com. 32, 355-361

Caliskan, M., Turet, M. \& Cuming, A.C. (2004). Formation of wheat (Triticum aestivum L.) embryogenic callus involves peroxide-generating germin-like oxalate oxidase. Planta 219, 132-140

Caliskan, M. (2009). Salt stress causes a shift in the localization pattern of germin gene expression. Gen. Mol. Res. 8, 1250-1256 
Cassab, G.I. \& Varner, J.E. (1989). Tissue printing on nitrocellulose paper: a new method for immunolocalization of proteins, localization of enzyme activities and anatomical analysis. Cell Biol. Inter. Rep. 13, 147-152

Chang, C.C. \& Beevers, H. (1968). Biogenesis of oxalate in plant tissues. Plant Physiol. 43, 1821-1828

Chen, X., Wang, M.L., Holbrook, C., Culbreath, A., Liang, X., Brenneman, T. \& Guo, B. (2011). Identification and characterization of a multigene family encoding germinlike proteins in cultivated peanut (Arachis hypogaea L.). Plant Mol. Biol. Rep. 29, 389-403

Chiriboga, J. (1966). Some properties of an oxalate oxidase purified from barley seedlings. Biochem. Biophys. Res. Commun. 116, 566-573

Cuming, A.C. (1984). Developmental regulation of gene expression in wheat embryos: Molecular clonong of a DNA sequence encoding the early-methionine-labelled (Em) polypeptide. Eur. J. Biochem. 145, 351-357

Datta, K., Parker, H., Averyhart-Fullard, V., Schmidt, A. \& Marcus, A. (1987). Gene expression in the soybean seed axis during germination and early seedling growth. Planta 170, 209-216

Davies, D.D. \& Asker, H. (1983). Synthesis of oxalic acid by enzymes from lettuce leaves. Plant Physiol. 72, 134-138

Delseny, M., Gaubier, P., Hull, G., Saez-Vasquez, J., Gallois, P., Raynal, M., Cooke, R. \& Grellet, F. (1994). Nuclear genes expressed during seed desiccation: Relationship with responses to stress. In: Stress-Induced Gene Expression in Plants, Basra, A.S. (Ed), 25-59. Harwood Academic Publishers

De Vries, S.C., Harmsen, M.C., Kuiper, M.T.R., Dons, H.J.M. \& Wessels, J.G.H. (1983). Molecular clonong of pea mRNAs encoding a shoot-specific polypeptide and light induced polypeptides. Plant Molecular Biology 2, 295-303

Domon, J.M., Dumas, B., Laine, E., Meyer, Y., David, A. \& David, H. (1995). Three glycosylated polypeptides secreted by several embryogenic cell cultures of pine show highly specific serological affinity to antibodies directed against the wheat germin apoprotein monomer. Plant Physiol. 108, 141-148

Donaldson, P.A., Anderson, T., Lane, B.G., Davidson, A.L. \& Simmonds, D.H. (2001). Soybean plants expressing an active oligomeric oxalate oxidase from the wheat gf2.8 (germin) gene are resistant to the oxalate-secreting pathogen Sclerotina sclerotiorum. Physiol. Mol. Plant Pathol. 59, 297-307

Dratewka-Kos, E., Rahman, S., Grzelczak, Z.F., Kennedy, T.D., Murray, R.K. \& Lane, B.G. (1989). Polypeptide Structure of Germin as Deduced from cDNA Sequencing. J. Biol. Chem. 264, 4896-4900

Dumas, B., Sailland, A., Cheviet, J-P., Freyssinet, G. \& Pallett, K. (1993). Identification of barley oxalate oxidase as a germin-like protein. C. R. Acad. Sci. Paris, Sciences de la vie/Life sciences 316, 793-798

Dumas, B., Freyssinet, G. \& Pallett, K.E. (1995). Tissue-specific expression of germin-like oxalate oxidase during development and fungal infection of barley seedling. Plant Physiol. 107: 1091-1096 
Dunwell, J.M., Khuri, S. \& Gane, P.J. (2000). Microbial relatives of the seed storage proteins of higher plants: Conservation of structure and diversification of function during evolution of the cupin superfamily. Microbiol. Mol. Biol. Rev. 64, 153-179

Dunwell, J.M., Gibbings, J.G., Mahmood, T. \& S.M. Saqlan Naqvi, S.M.S. (2008). Germin and germin-like proteins: evolution, structure, and function. Crit. Rev. Plant Sciences 27, 342-375

Dure III, L. (1985). Embryogenesis and gene expression during seed formation. Oxford Surv. Plant Mol. Cell Biol. 2, 179-197

Emsley, J. (1994). Rhubarb toxin found in blood. New Scientist, pp. 17

Fincher, G.B. (1989). Molecular and cellular biology associated with endosperm mobilization in germinating cereal grains. Ann. Rev. Plant Physiol. Plant Mol. Biol. 40, 305-346

Flowers, T.J., Troke, P.F. \& Yeo, A.R. (1977). The mechanism of salt tolerance in halophytes. Ann. Rev. Plant Phsiol. 28, 89-121

Franceschi, V.R. (1989). Calcium oxalate formation is a rapid and reversible process in Lemna minor L. Protoplasma 148, 130-137

Galau, G.A., Jakobsen, K.S. \& Hughes, D.W. (1991). The controls of late dicot embryogenesis and early germination. Physiol. Plant. 81, 280-288

Gibeaut, D.M. \& Carpita, N.C. (1991). Tracing cell wall biogenesis in intact cells and plants: selective turnover and alteration of soluble and cell wall polysaccharides in grasses. Plant Physiol. 97, 551-561

Goldberg, R.B., Barker, S.J. \& Perez-Grau, L. (1989) Regulation of gene expression during plant embryogenesis. Cell 56, 149-160

Greenway, H. \& Munns, R. (1980). Mechanisms of salt tolerance in nonhalophytes Ann. Rev. Plant Physiol. 31, 149-190

Grzelczak, Z.F., Sattolo, M.H., Hanley-Browdoin, L.K., Kennedy, T.D. \& Lane, B.G. (1982). Synthesis and turnover of proteins and mRNA in germinating wheat embryos. Can. J.Biochem. 60, 389-397

Grzelczak, Z.F. \& Lane, B.G. (1983). The growth-related 28-kilodalton protein in germinating wheat. Use of peptide mapping to identify cryptic forms in cell-free extracts and protein-synthesizing systems. Can. J. Biochem. Cell Biol. 61, 1233-1243

Grzelczak, Z.F. \& Lane, B.G. (1984). Signal resistance of a soluble protein to enzymic proteolysis. An unorthodox approach to the isolation and purification of germin , a rare growth-related protein. Can. J. Biochem. Cell Biol. 62, 145-149

Grzelczak, Z.F., Rahman, S., Kennedy, T.D. \& Lane, B.G. (1985). Germin. Compartmentation of the protein, its translatable mRNA, and its biosynthesis among roots, stems, and leaves of wheat seedling. Can. J. Biochem. Cell Biol. 63, 1003-1013

Heintzen, C., Melzer, S., Fischer, R., Kappeler, S., Apel, K. \& Staiger, D. (1994). A light- and temperature-entrained circadian clock controls expression of transcripts encoding nuclear proteins with homology to RNA-binding proteins in meristematic tissue. The Plant Journal 5(6), 799-813

Hepler, P.K. \& Wayne, R.O. (1985). Calcium and plant development. Ann. Rev. Plant Physiol. 36, 397-439

Hodgkinson, A. (1977). Oxalic acid in biology and medicine. Academic Press London 
Hofte, H., Desprez, T., Amselem, J., Chiapello, H., Caboche, M., Moisan, A., Jourjon, M.F., Charpenteau, J.L., Berthomieu, P., Guerrier, D., Girauda, J., Quigley, F., Thomas, F., Yu, D-Y., Mache, R., Raynal, M., Cooke, R., Grellet, F., Delseny, M., Parmentier, Y., Marcillac, G.D., Gigot, C., Fleck, J., Philipps, G., Axelos, M., Bardet, C., Tremousaygue, D. \& Lescure, B. (1993). An inventory of 1152 expressed sequence tags obtained by partial sequencing of cDNAs from Arabidopsis thaliana. The Plant Journal 4(6), 1051-1061

Hurkman, W.J., Fornari, C.S. \& Tanaka, C.K. (1989). A comparison of the effect of salt on polypeptides and translatable mRNAs in roots of a salt-tolerant and a salt-sensitive cultivar of barley. Plant Physiol. 90, 1444-1456

Hurkman, W.J., Tao, H.P. \& Tanaka, C.K. (1991). Germin-like polypeptides increase in barley roots during salt stress. Plant Physiol. 97, 366-374

Hurkman, W.J., Lane, B.G. \& Tanaka, C.K. (1994). Nucleotide Sequence of a Transcript Encoding a Germin-Like Protein That Is Present in Salt-Stressed Barley (Hordeum vulgare L.) Roots. Plant Physiol. 104, 803-804

Hurkman, W.J. \& Tanaka, C.K. (1996a). Effect of salt stress on germin gene expression in barley roots. Plant Physiol. 110, 971-977

Hurkman, W.J. \& Tanaka, C.K. (1996b). Germin gene expression is induced in wheat leaves by powdery mildew infection. Plant Physiol. 111, 735-739

Jaikaran, A.S.I., Kennedy, T.D., Dratewka-Kos, E. \& Lane, B.G. (1990). Covalently Bonded and Adventitious Glycans in Germin. J. Biol. Chem. 265, 12503-12512

Jendrisak, J. (1980). The use of $\alpha$-amanitin to inhibit in vivo RNA synthesis and germination in wheat embryos. J. Biol. Chem. 255, 8529-8533

Keates, S.A., Zhang, D., Loewus, F.A. \& Franceschi, V.R. (1996). Oxalate oxidase is synthesized and secreted from bean leaf cells in response to fungal infection. Plant Physiol. 111, 311-311

Konomi, K., Abe, H. \& Furuya, M. (1987). Changes in the content of phytochrome I and II apoproteins in embryonic axes of pea seeds during imbibition. Plant Cell Physiol. 28(8), 1443-1451

Koyama, H. (1988). Purification and characterization of oxalate oxidase from Pseudomonas sp. OX-53. Agric. Biol. Chem. 52, 743-748

Kuan, I.C. \& Tien, M. (1993). Stimulation of Mn peroxidase activity: a possible role of oxalate in lignin biodegradation. Proc. Natl. Acad. Sci. USA 90, 1242-1246

Kuchhal, N.K., Satyapal \& Pundir, C.S. (1993). Partial purification, some properties and possible physiological role of an oxalate oxidase from grain sorghum leaves. Indian J. Plant Physiol. 36(3), 159-162

Laker, M.F., Hofmann, A.F. \& Meeuse, B.J. (1980). Spectrophotometric determination of urinary oxalate with oxalate oxidase prepared from moss. Clin. Chem. 26, 827-830

Lane, B.G. \& Tumaitis-Kennedy, T.D. (1981). Comparative study of levels of secondary processing in bulk mRNA from dry and germinating wheat embryos. Eur. J. Biochem. 114, 457-463

Lane, B.G., Grzelczak, Z.F., Kennedy, T.D., Hew, C. \& Joshi, S. (1987). Preparation and analysis of mass amounts of germin: demonstration that the protein which signals 
the onset of growth in germinating wheat is a glycoprotein. Biochem. Cell Biol. 65, 354-362

Lane, B.G. (1988). The wheat embryo, then and now. In: The roots of modern biochemistry, Kleinkauf, H., Von Dohren, H. \& Jaenicke, L. (Eds), 457-476, Walter de Gruyter and co., New York

Lane, B.G. (1991). Cellular desiccation and hydration: developmentally regulated proteins, and the maturation and germination of seed embryos. FASEB J. 5, 2893-2901

Lane, B.G., Bernier, F., Dratewka-Kos, E., Shafai, R., Kennedy, T.D., Pyne, C., Munro, J.R., Vaughan, T., Walters, D. \& Altomare, F. (1991). Homologies between members of the germin gene family in hexaploid wheat and similarities between these wheat germins and certain Physarum spherulins. J. Biol. Chem. 266, 10461-10469

Lane, B.G., Cuming, A.C., Fregeau, J., Carpita, N.C., Hurkman, W.J., Bernier, F., DratewkaKos, E., \& Kennedy, T.D. (1992). Germin isoforms are discrete temporal markers of wheat development: pseudogermin is uniquely thermostable water-soluble oligomeric protein in ungerminated embryos and like germin in germinated embryos, it is incorporated into cell walls. Eur. J. Biol. Chem. 209, 961-969

Lane, B.G., Dunwell, J.M., Ray, J.A., Schmitt, M.R. \& Cuming, A.C. (1993). Germin, a protein marker of early plant development, is an oxalate oxidase. J. Biol. Chem. 268: 1223912242

Lane, B.G. (1994). Oxalate, germin, and the extracellular matrix of higher plants. FASEB J., 8 , 294-301

Lane, B.G. (2000). Oxalate oxidases and differentiating surface structure in wheat: germin. Biochem J. 349, 309-321

Lane, B.G. (2002). Oxalate, Germins, and Higher-Plant Pathogens. IUBMB Life 53, 67-75

Leek, A.E., Halliwell, B. \& Butt, V.S. (1972). Oxidation of formate and oxalate in peroxisomal preparations from leaves of spinach beet (Beta vulgaris L.). Biochim. Biophys. Acta 286, 299-311

Leopold, A.C., Bruni, F. \& Williams, R.J. (1992). Water in dry organisms. In: Water and life, G. Somero, C.B. Osmond \& R.J. Williams (Eds), 161-169, Springer-Verlag, Berlin

Luttrel, B.M. (1993). The biological relevance of the binding of calcium ions by inositol phosphates. J. Biol. Chem. 268, 1521-1524

Marcus, A., (1969). Seed germination and the capacity for protein synthesis. Symp. Soc. Exp. Biol. 23, 143-160

McCubbin, W.C., Kay, C.M., Kennedy, T.D. \& Lane, B.G. (1987). Germin: physicochemical properties of the glycoprotein which signals onset of growth in the germinating wheat embryo. Biochem. Cell Biol. 65, 1039-1048

Maxwell, D.P. \& Bateman, D.F. (1968). Influence of carbon source and pH on oxalate accumulation in culture filtrates of

Sclerotium rolfsii. Phytopathology 58, 1351-1355

Meeuse, B.J.D. \& Campbell, J.M. (1959). An inhibitor of oxalic acid oxidase in beet extracts. Plant Physiol. 34, 583-586

Michalowski, C.B. \& Bohnert, H.J. (1992). Nucleotide sequence of a root-specific transcript encoding a germin-like protein from the halophyte Mesembryanthemum crystallinum. Plant Physiol. 100, 537-538 
Millerd, A., Morton, R.K. \& Wells, J.R.E. (1963). Oxalic acid synthesis in shoots of Oxalis pescaprae L. Biochem. J. 86, 57-62

Moreland, D.E., Hussey, G.G., Shriner, C.R., \& Farmer, F.S. (1974). Adenosine phosphates in germinating radish (Raphanus sativus L.) seeds. Plant Physiol. 54, 560-563

Myers, A.T. (1947). Seasonal changes in total and soluble oxalates in leaf blades and petioles of rhubarb. J. Agric. Res. 74, 33-47

Nakata, M., Shiono, T., Watanabe, Y. \& Satoh, T. (2002). Salt stress-induced dissociation from cells of a Germin-Like Protein with Mn-SOD activity and an increase in its mRNA in a moss, Barbula unguiculata. Plant Cell Physiol. 43, 1568-1574

Noyes, R.D. \& Hancock, J.G. (1981). Role of oxalic acid in the Sclerotinia wilt of sunflower. Physiol. Plant Pathol. 18, 123-132

Obzansky, D.M. \& Richardson, K.E. (1983). Quantification of urinary oxalate with oxalate oxidase from beet stems. Clin. Chem. 29, 1815-1819

Ono, M., Sage-Ono, K., Inoue, M., Kamada, H. \& Harada, H. (1996). Transient increase in the level of mRNA for a germin-like protein in leaves of the short-day plant Pharbitis nil during the photoperiodic induction of flowering. Plant Cell Physiol. 37, 855-861

Ozcan, B., Cokmus, C., Coleri, A. \& Caliskan, M. (2006). Characterization of extremely halophilic archaea isolated from saline environment in different parts of Turkey. Microbiology 75, 739-746

Ozcan, B., Ozcengiz, G., Coleri, A., Cokmus, C. (2007). Diversity of halophilic archaea from six distinct parts of Turkey. J. Microbiol. Biotechnol. 17, 985-992

Petrarulo, I.S., Bianco, O., Marangella, M., Pellegrino, S. \& Linari, F. (1990). Ion chromotographic determination of plasma oxalate in healthy subjects, in patients with chronic renal failure and in cases of hyperoxaluric syndromes. $J$. Chromatography 511, 285-291

Pietta, P.G., Calatroni, A., Agnellini, D. \& Pace, M. (1982). Improved purification protocol for oxalate oxidase from barley roots. Preparative Biochem. 12, 341-353

Polson, C.J. \& Tattersall, R.N. (1959). Clinical Toxicology. English Univ. Press London

Pundir, C.S. \& Nath, R. (1984). Occurrence of an oxalate oxidase in Sorghum leaves. Phytochemistry 23, 1871-1874

Pundir, C.S., Nath, R. \& Thind, S.K. (1985). Enzymatic assay of oxalate oxidase from sorghum leaves. In: Urolithiasis and Related Clinical Research, P.O. Schwille, L.H. Smith, W.G. Robertson and W. Vahlensieck (Eds), 657-660, Plenum Press New York

Pundir, C.S. \& Kuchhal, N.K. (1989). Detection of an oxalate oxidase in grain Sorghum leaves. Phytochemistry 28, 2909-2912

Pundir, C.S. (1991). Purification and properties of oxalate oxidase from Sorghum leaves. Phytochemistry 30, 1065-1067

Raghwan, K.G. \& Devasagayam, T.P.A. (1985). Oxalate oxidase from banana peel for determination of urinary oxalate. Clin. Chem. 31, 649-652

Rahman, S., Grzelczak, Z.F., Kennedy, T.D. \& Lane, B.G. (1988). Germin. Molecular cloning of cDNA that selects germin mRNA from bulk wheat mRNA. Biochem. Cell Biol. 66, 100-106 
Ranjhan, S., Karrer, E.E. \& Rodriguez, R.L. (1992). Localizing $\alpha$-amylase gene expression in germinating rice grains. Plant Cell Physiol. 33, 73-79

Raven, J.A. \& Smith, F.A. (1976). Nitrogen assimilation and transport in vascular land plants in relation to intracellular $\mathrm{pH}$ regulation. New Phytol. 76, 415-431

Rogers, S.O. \& Quatrano, R.S. (1983). Morphological staging of wheat caryopsis development. Amer. J. Bot. 70(2), 308-311

Roth, D.A. \& Breitenfield, R.V. (1977). Vitamin C and oxalate stones. J. Am Med. Ass. 237, 768-768

Satyapal \& Pundir, C.S. (1993). Purification and properties of an oxalate oxidase from leaves of grain sorghum hybrid CSH-5. Biochim. Biophys. Acta 1161, 1-5

Sharma, S., Vaidyanathan, S., Nath, R. \& Thind, S.K. (1991). Advances in pathophysiology of calcium oxalate stone disease. Ind. J. Urol. 8, 25-37

Showalter, A.M. (1993). Structure and function of plant cell wall proteins. The Plant Cell 5, 923

Srivastava, S.K. \& Krishnan, P.S. (1959). Oxalate content of plant tissues. J. Sci. Industr. Res. 18C, 146-148

Srivastava, S.K. \& Krishnan, P.S. (1962). An oxalic acid oxidase in leaves of Bougainvillea spectabilis. Biochem. J. 85, 33-38

Sticher, L., Penel, C. \& Greppin, H. (1981). Calcium requirement for the secretion of peroxidases by plant cell suspensions. J. Cell Sci. 48, 345-353

Stutz, R.E. \& Burris, R.H. (1951). Photosynthesis and metabolism of organic acids in higher plants. Plant Physiol. 26, 226-243

Sugiura, M., Yamamura, H., Hirano, K., Sasaki, M., Morikawa, M. \& Tsuboi, M. (1979). Purification and properties of oxalate oxidase from barley seedlings. Chem. Pharm. Bull. 27, 2003-2007

Tavant, H. (1967). Fixation de ${ }^{14} \mathrm{CO}_{2}$ et absorption de glucose-U-14C par des feuilles de Begonia semperflorens Link et otto. Etude des conditions de la genese de l'acide oxalique. Physiol. Veg. 5, 57-69

Thompson, F.B. \& Lane, B.G. (1980). Relation of Protein Synthesis in Imbibing Wheat Embryos to the Cell-free Translational Capacities of Bulk mRNA from dry and Imbibing Embryos. J. Biol. Chem. 255, 5965-5970

Thompson, C., Dunwell, J.M., Johnstone, C.E., Lay, V., Schmitt, M., Watson, H. \& Nisbet, G. (1995). Degradation of oxalic acid by transgenic oilseed rape plants expressing oxalate oxidase. Euphytica 85, 169-172

Vaisey, E.B., Cheldelin, V.H. \& Newburgh, R.W. (1961). Oxalate oxidation by an obligately parasitic fungus Tilletia controversa. Arch. Biochem. Biophys. 95, 66-69

Vincent, R.F. \& Harry, T.H. JR. (1980). Calcium oxalate crystals in plants. Bot. Rev. 46, 361427

Wagner, G.J. (1981). Vacuolar deposition of ascorbate-derived oxalic acid in barley. Plant Physiol. 67, 591-593

Webb, M.A., Cavaletto, J.M., Carpita, N.C., Lopez, L.E. \& Arnott, H.J. (1995). The intravacoular organic matrix associated with calcium oxalate crystals in leaves of Vitis. The Plant Journal 7(4), 633-648 
Wu, G., Shortt, B.J., Lawrence, E.B., Levine, E.B., Fitzsimmons, K.C. \& Shah, D.M. (1995). Disease resistance conferred by expression of a gene encoding $\mathrm{H} 2 \mathrm{O} 2$-generating glucose oxidase in transgenic potato plants. The Plant Cell 7, 1357-1368

Yamahara, T., Shiono, T., Suzuki, T., Tanaka, K., Takio, S., Sato, K., Yamazaki, S. \& Satoh, T. (1999). Isolation of a germin-like protein with manganese superoxide dismutase activity from cells of a moss, Barbula unguiculata. J. Biol. Chem. 274, 33274-33278

Yang, J.C. \& Loewus, F.A. (1975). Metabolic conversion of Lascorbic acid to oxalic acid in oxalate-accumulating plants. Plant Physiol. 56, 283-285

Zhang, Z., Collinge, D.B. \& Thordal-Christensen, H. (1995). Germin-like oxalate oxidase, a $\mathrm{H}_{2} \mathrm{O}_{2}$-producing enzyme, accumulates in barley attacked by the powdery mildew fungus. The Plant Journal 8(1), 139-145 


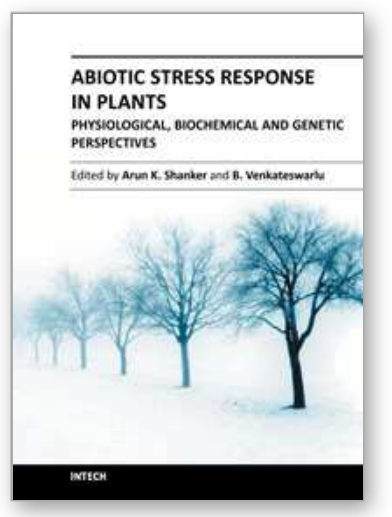

\author{
Abiotic Stress Response in Plants - Physiological, Biochemical \\ and Genetic Perspectives \\ Edited by Prof. Arun Shanker
}

ISBN 978-953-307-672-0

Hard cover, 346 pages

Publisher InTech

Published online 29, August, 2011

Published in print edition August, 2011

Plants, unlike animals, are sessile. This demands that adverse changes in their environment are quickly recognized, distinguished and responded to with suitable reactions. Drought, heat, cold and salinity are among the major abiotic stresses that adversely affect plant growth and productivity. In general, abiotic stress often causes a series of morphological, physiological, biochemical and molecular changes that unfavorably affect plant growth, development and productivity. Drought, salinity, extreme temperatures (cold and heat) and oxidative stress are often interrelated; these conditions singularly or in combination induce cellular damage. To cope with abiotic stresses, of paramount significance is to understand plant responses to abiotic stresses that disturb the homeostatic equilibrium at cellular and molecular level in order to identify a common mechanism for multiple stress tolerance. This multi authored edited compilation attempts to put forth an all-inclusive biochemical and molecular picture in a systems approach wherein mechanism and adaptation aspects of abiotic stress are dealt with. The chief objective of the book hence is to deliver state of the art information for comprehending the effects of abiotic stress in plants at the cellular level.

\title{
How to reference
}

In order to correctly reference this scholarly work, feel free to copy and paste the following:

Mahmut Caliskan (2011). The Roles of Germin Gene Products in Plants Under Salt Stress, Abiotic Stress Response in Plants - Physiological, Biochemical and Genetic Perspectives, Prof. Arun Shanker (Ed.), ISBN: 978-953-307-672-0, InTech, Available from: http://www.intechopen.com/books/abiotic-stress-response-inplants-physiological-biochemical-and-genetic-perspectives/the-roles-of-germin-gene-products-in-plants-undersalt-stress 1

\section{INTECH}

open science | open minds

\section{InTech Europe}

University Campus STeP Ri

Slavka Krautzeka 83/A

51000 Rijeka, Croatia

Phone: +385 (51) 770447

Fax: +385 (51) 686166

www.intechopen.com

\section{InTech China}

Unit 405, Office Block, Hotel Equatorial Shanghai

No.65, Yan An Road (West), Shanghai, 200040, China 中国上海市延安西路65号上海国际贵都大饭店办公楼 405 单元

Phone: +86-21-62489820

Fax: $+86-21-62489821$ 
(C) 2011 The Author(s). Licensee IntechOpen. This chapter is distributed under the terms of the Creative Commons Attribution-NonCommercialShareAlike-3.0 License, which permits use, distribution and reproduction for non-commercial purposes, provided the original is properly cited and derivative works building on this content are distributed under the same license. 